\title{
Is it a friend or an enemy? A study on the relationship between job friendships and job performance of Hospitality employees- Organizational commitment as mediating variable
}

\author{
Chao Chia-Wei ${ }^{1 a}$ \\ ${ }^{1}$ Tourism School of Wuyi University, Wuyishan City, Fujian Province, 354300 \\ a1991150933@qq.com
}

\begin{abstract}
Keywords: Workplace friendship, Organizational Commitment, Job performance, the Hospitality industry
\end{abstract}

\begin{abstract}
While work friendship, organizational commitment and job performance have been extensively investigated, the relationship between the above three research fields is relatively unexplored. This paper studies the three constructs relationship and mediating of organizational commitment situation. Using the hospitality industry employees as an example, this paper will argue that the regression analysis can provide a framework for workplace friendship has a positive impact on organizational commitment, as well as giving workplace friendship has a positive impact on job performance, and a method of analyzing organizational commitment has a positive impact on job performance, and find organizational commitment has a mediating effect on workplace friendship and job performance. The results indicate that that all hypotheses are set up. These findings contribute to the organizational management and theoretical construction of the hospitality industry.
\end{abstract}

\section{Introduction}

There has been an increasing interest in research on the relationship between workplace and organizational performance. For instance, Berman, West and Richer believes that workplace friendship is a spontaneous, informal and intimate interpersonal relationship between employees and their colleagues in the working environment[1], and Nielsen, Jex, and Adam mentioned the influence of interpersonal relationship on employees' work attitude and turnover intention[2]. Winstead, Derlega, Montgomery, and Pilkington found that workplace friendships had positive effects on work related attitudes and behaviors, such as job satisfaction and job performance[3]. Krackhard and Stem concluded that when there are crises, employees who have friends with other departments will get more cooperation and help[4]. On the other hand, they found that organizations with high organizational commitment employees have higher organizational performance and lower employee turnover rate[5], Han, Liao, and Long believe that affective commitment is related to employee's role performance, extra role performance and innovation performance, but the degree of connection is different [6]. It is known that workplace friendship not only affects individual's work attitude and behavior, such as job performance, but also on organizational behavior, such as employee cooperation or team emotional support. However, there are few researches in the past. Therefore, the purpose of this study is to understand the relationship between three factors, namely workplace friendship, organizational commitment and job performance.

\section{Literature review}

The workplace friendship is proposed by Hackman and Oldham [7], in past studies, workplace friendship is a spontaneous behavior, through interpersonal interaction, a common effort and mutual help behavior of interpersonal relationship[8][9][10]; At the same time, the research also points out that good workplace friendships will encourage employees to trust organizations more and produce more commitment and identity to the organization, when communication is non-task oriented, the 
organizational commitment of employees will also be promoted[11], past research results also support workplace friendships, which positively affect organizational commitment[12][13]; On the other hand, it is also found that friendship opportunities can promote employee interaction and improve job performance[14]. Therefore, this study proposes the following hypothesis 1 and 2:

$\mathrm{H} 1$ : the workplace friendship has a positive impact on organizational commitment.

$\mathrm{H} 2$ : the workplace friendship has a positive impact on work performance.

Organizational commitment is proposed by Becker[11], Rotundo and Sackett think that job performance refers to individuals' accomplishing organizational goals in a certain period of time through a series of behaviors[15]. Randall research shows that organizational commitment is positively correlated with job performance[16], and a number of studies suggest that organizational commitment can promote task performance and relationship performance by improving employee motivation and work input[17][18]. Therefore, this study puts forward hypothesis 3 and 4:

H3: the organizational commitment has a positive impact on work performance.

$\mathrm{H} 4$ : the organizational commitment has a mediating effect on workplace friendship and job performance.

\section{Method and Data Analysis}

In this study, the workplace friendship questionnaire was quoted from Sun and Jiao[19], organizational commitment from Meyer and Allne[20]. The work performance was quoted from Borman and Motowidlo [21] scale, the pre-test and formal questionnaire were carried out from January to March 2018, and the employees of high star hotels in Fuzhou and Xiamen in Fujian were sampled by means of intention sampling, and 300 questionnaires were collected effectively. The method of reliability analysis, factor analysis, regression analysis and Sobel test were used to test the hypothesis. The reliability of the workplace friendship Cronbach's alpha is 0.885 , organizational commitment is 0.915 , and job performance is 0.931 , and the validity of the above three dimensions is more than 0.7 . The results of hypothesis are shown in Table 1 as follows. From table 1, we can know that the hypothesis 1.2 and 3 are established, using Sobel test verification, the total effect is 0.7111 ( $p$-value $=0.000)$, the direct effect is 0.6159 ( $p$-value $=0.000)$, the indirect effect is 0.0952 ( $p$-value $=0.0146)$, and the result hypothesis that 4 is also accepted.

Table 1 Hypothesis validation result table

\begin{tabular}{ccccccc}
\hline $\begin{array}{c}\text { Hypothes } \\
\text { is }\end{array}$ & $R^{2}$ & $F$ & B & Beta & $t$-value & Accept or Reject \\
\hline H1 & 0.552 & $367.022^{* * *}$ & 0.711 & 0.743 & $8.628^{* * *}$ & Accept \\
H2 & 0.523 & $327.300^{* * *}$ & 0.758 & 0.723 & $18.091^{* * *}$ & Accept \\
H3 & 0.364 & $170.266^{* * *}$ & 0.551 & 0.603 & $13.049^{* * *}$ & Accept \\
\hline Note: ${ }^{*} P<0.05$ & ${ }^{* *} P<0.01$ & ${ }^{* * *} P<0.001$ & & & &
\end{tabular}

\section{Summary}

This study explores the relationship between the three aspects of workplace friendship, organizational commitment and work performance. The overall results show that the better the employee's workplace friendship is, the higher the employee's sense of identity is, the higher the employee's commitment to the organization, and therefore, it will also affect the job performance. In addition, it shows that the higher the organization promises, the more loyal to the organization, the more willing to do their own job, and even the work that is beneficial to the development of the organization. Finally, the influence of organizational commitment, the impact of the workplace friendship on the work performance will be enhanced, and the good workplace friendship can be known from this study. The relationship not only increases employees' organizational performance, but also increases the effectiveness of work performance in the condition of increasing organizational commitment. This result hopes to give practical and theoretical support and 
contribution to the practical and academic circles.

\section{References}

[1] Berman E M, West J P, Richer Jr M N. Workplace relations: Friendship patterns and consequences, Public Administration review, vol. 62, pp. 217-230, 2002.

[2] Nielsen I K, Jex S M, Adams G A. Development and validation of scores on a two-dimensional workplace friendship scale, Educational and psychological measurement, vol. 60, pp. 628-643, 2000.

[3] Winstead B A, Derlega V J, Montgomery M J, Pilkington C. The quality of friendships at work and job satisfaction, Journal of Social and Relationship, vol. 12, pp.199-215, 1995.

[4] Krackhardt D, Stern R N. Informal networks and organizational crises: An experimental simulation, Social Psychology Quarterly, vol. 51, pp. 123-140, 1988.

[5] $\mathrm{Hu} \mathrm{W}$ P, Shi K. A review of the research about organizational commitment, Advances in Psychological Science, vol. 12, pp. 103-110, 2004.

[6] Han Y, Liao J Q, Long L R. Model of development and empirical study on employee job performance construct, Journal of Management Sciences in China, vol. 10, pp.62-77,2007.

[7] Hackman J R, Oldham G R. Development of the job diagnostic survey, Journal of applied psychology, vol. 60, pp.159-170, 1975.

[8] Wright P H. Self-referent motivation and the intrinsic quality of friendship, Journal of social and personal relationships, vol.1, pp.115-130, 1984.

[9] Song S H, Olshfski D. Friends at work: a comparative study of work attitudes in Seoul City government and New Jersey State government, Administration and Society, vol.40, pp. 147-169, 2008

[10] Sias P M, Gallagher E B, Kopaneva I, et al. Maintaining workplace friendships: Perceived politeness and predictors of maintenance tactic choice, Communication Research, vol.39, pp. 239-268, 2012.

[11]Becker H S. Notes on the concept of commitment, American journal of sociology, vol. 66, pp. 32-42, 1960.

[12] Teimouri M, Hamid I B A. The relationship between workplace friendship and organization commitment, Ache development international conference, 2011.

[13]Hsieh A T, Yang S S. The Impact of Workplace Friendship on Organizational Identification-Job Satisfaction and Group Cohesiveness as Mediator Variables, Journal of Humanities and Social Sciences, vol. 7, pp. 77-90, 2011.

[14] Barsade S G. The ripple effect: Emotional contagion and its influence on group behavior. Administrative Science Quarterly, vol. 62, pp. 217-230, 2002.

[15] Rotundo M, Sackett P S. The relative importance of task, citizenship and counterproductive performance to global ratings of job performance: A policy capturing approach, Journal of Applied Psychology, vol. 87, pp. 66-80, 2002.

[16] Randall D M, Fedor D.B, Longenecker C O. The Behavior Expression of Organizational Commitment, Journal of Vocational Behavior, vol. 36, pp. 18-23, 1999.

[17] Parker C P, Baltes B B, Young S A. Relationship between Psychological Climate Perceptions and Work Outcomes: A Mete-analytic Review, Journal of Organizational Behavior, vol. 24, pp. 
389-416, 2003.

[18] Rego A, Cunha M P. Workplace spirituality and organizational commitment: An empirical study, Journal of Organizational Change Management, vol. 21, pp. 53-75, 2007.

[19] Sun J M, Jiao H T. Workplace friendship in Chinese context, Economic management, vol. 34, pp. 62-70, 2012.

[20] Meyer J P, Allen N J. Commitment in the workplace: Theory, research and application, Thousand Oaks: Sage Publications, 1997.

[21] Borman W C Motowidlo S J. Expanding the criterion domain to include element of contextual performance, In: Schmitt, N. and Borman, W.C., Eds., Personnel Selection in Organizations, Wiley, New York, 71-98, 1993. 